\title{
A esperança é um contraponto: Poesia de Bhuchung D. Sonam
}

\author{
Claudia Santana Martins
}

Resumo: Este artigo apresenta traduções para o português de dois poemas de Bhuchung D Sonam, escritor tibetano no exílio.

Palavras-chave: Bhuchung D. Sonam; Tibete; exílio; poesia

Abstract: This article presents poetic translation of two of exile Tibetan writer Bhuchung D Sonam's poems from English into Brazilian-Portuguese.

Keywords: Bhuchung D Sonam; Tibet; exile; poetry 


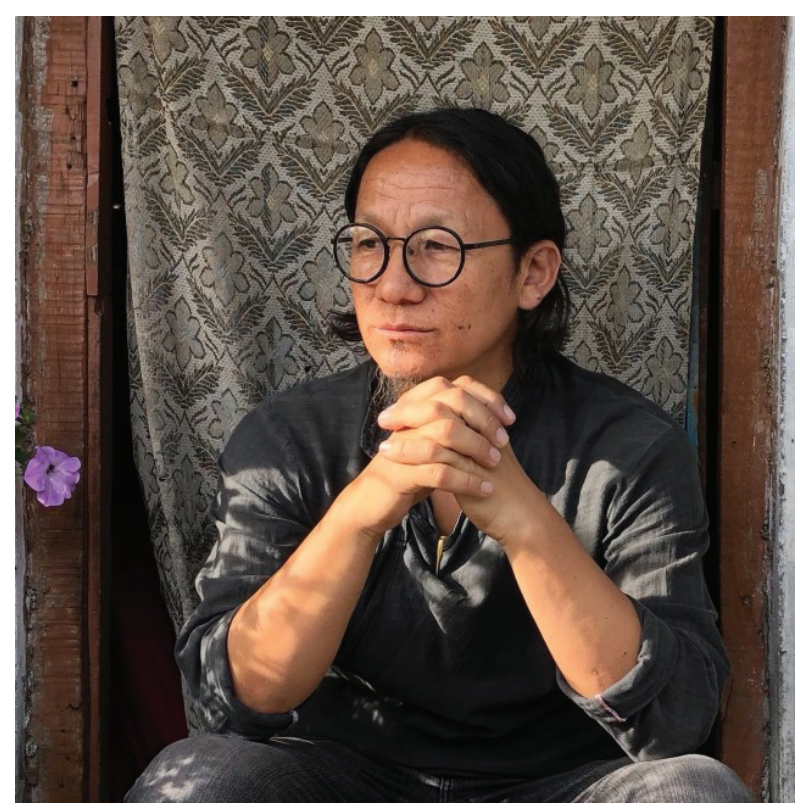

\section{Sobre o poeta}

Bhuchung D. Sonam é autor de diversos livros, entre os quais Yak Horns: Notes on Contemporary Tibetan Writing, Music, Film \& Politics e Songs of the Arrow. Organizou o livro Muses in Exile: An Anthology of Tibetan Poetry e compilou e traduziu Burning the Sun's Braids: New Poetry from Tibet.

Seus artigos são publicados no Journal of Indian Literature, HIMAL Southasian, Hindustan Times e Tibetan Review, entre outras revistas e periódicos.

Sua residência permanente lhe foi roubada. 


\title{
Os poemas e as traduções
}

\section{When was I Born?}

\author{
Mother, when was I born?
}

In the year the river dried

When was that?

That was the year when crops failed And we went hungry for many days We feared that you would never survive

Was that the year we moved to a new house?

That was the year when they confiscated our house And divided it among the patriotic Party members We were banished to the cowshed where you were born

\section{What year was that?}

That was the year when they destroyed the monastery Melted all the bronze images to make bullets You were born when dust filled the sky

\section{Was that the year grandpa went away?}

That was the year when they sent your grandfather to prison Where he cleaned shit and butchered insects in the fields You were born when there were no men in our house

Was I born in the year the walls were pulled down?

That was the year when they ripped apart the prayer hall Wooden beams were hammered to splinters and frescoes soiled You were born when a crazy wind blew from the east

\section{What year was that?}

That was the year they burnt scriptures in the village square And sang revolutionary songs in praise of the Party You were born when blades of grass refused to grow 
Was it the year you stopped singing?

It was the year they took our neighbour to the hard labour camp When she sang a traditional song while digging a canal You were born when people disappeared one after another

\section{When was that?}

That was the year they wrote the big red slogan on the walls 'Heads that stick out will be hammered down' You were born when the sun shied away from our sky

\section{When was that?}

That was the year when your father... your father 


\title{
Quando eu nasci?
}

\author{
Mãe, quando eu nasci?
}

No ano em que o rio secou

\section{Quando foi isso?}

Esse foi o ano em que as colheitas se perderam E passamos fome por muitos dias Temíamos que você não sobrevivesse

\section{Foi nesse ano que nos mudamos para uma nova casa?}

Esse foi o ano em que eles confiscaram nossa casa $\mathrm{E}$ a dividiram entre os patrióticos membros do Partido Nós fomos expulsos para o estábulo onde você nasceu

\section{Que ano foi esse?}

Esse foi o ano em que eles destruíram o mosteiro Derreteram todas as estátuas de bronze para fazer balas Você nasceu quando a poeira cobriu o céu

\section{Foi nesse ano que vovô foi embora?}

Esse foi o ano em que eles mandaram o seu avô para a prisão Onde ele limpava a merda e exterminava insetos nos campos Você nasceu quando não havia homens em nossa casa

\section{Eu nasci no ano em que as paredes foram demolidas?}

Esse foi o ano em que eles destroçaram a sala de oração Vigas de madeira foram estilhaçadas a golpes de martelo e os afrescos vandalizados Você nasceu quando um vento insano soprou do leste

\section{Que ano foi esse?}

Esse foi o ano em que eles queimaram escrituras na praça da vila E entoaram canções revolucionárias em louvor ao Partido

Você nasceu quando os rebentos de relva se recusavam a crescer

\section{Foi nesse ano que você parou de cantar?}

Foi o ano em que eles levaram nossa vizinha para o campo de trabalhos forçados Porque ela cantou uma canção tradicional enquanto cavava um canal Você nasceu quando as pessoas desapareciam uma após a outra 


\section{Quando foi isso?}

Esse foi o ano em que eles escreveram o grande slogan vermelho nos muros "As cabeças que se sobressaírem levarão marteladas" Você nasceu quando o sol fugiu de nosso céu

\section{Quando foi isso?}

Esse foi o ano em que o seu pai... o seu pai

\section{Untitled}

Hope is a counterpoint to disappointment,

I wear it like

a belt whose holes

widen each day.

When the sun admonishes

I cram my head into

the refrigerator

to reaffirm

my allegiance to

the cold mountains. 


\title{
Sem título
}

\author{
A esperança é \\ um contraponto ao \\ desapontamento, \\ Eu a uso como \\ um cinto cujos furos \\ aumentam a cada dia. \\ * \\ Quando o sol alerta \\ Enfio a cabeça \\ no refrigerador \\ para reafirmar \\ minha lealdade \\ às montanhas geladas.
}

Cláudia Santana Martins é doutora em Letras na área de Estudos Linguísticos e Literários em Inglês, pela Faculdade de Filosofia, Letras e Ciências Humanas da Universidade de São Paulo, onde também fez seu pós-doutorado em Estudos de Tradução. 